\title{
Massive expansion of regulatory T-cells following interleukin 2 treatment during a phase I-II dendritic cell-based immunotherapy of metastatic renal cancer
}

\author{
FRANÇOIS M. LEMOINE ${ }^{1 *}$, MUSTAPHA CHERAI ${ }^{1 *}$, CAMILLE GIVERNE $^{1}$, DALIA DIMITRI ${ }^{2}$, \\ MICHELLE ROSENZWAJG ${ }^{1}$, HELENE TREBEDEN-NEGRE ${ }^{1}$, NATHALIE CHAPUT ${ }^{1}$, BENOIT BARROU ${ }^{3}$, \\ NICOLAS THIOUN ${ }^{4}$, BERNARD GATTEGNIO ${ }^{5}$, FREDERIC SELLES ${ }^{6}$, ALAIN SIX ${ }^{7}$, NABIH AZAR $^{2}$, \\ JEAN PIERRE LOTZ ${ }^{6}$, AGNES BUZYN ${ }^{8}$, MATHILDE SIBONY $^{9}$, ANNICK DELCOURT ${ }^{10}$, \\ OLIVIER BOYER ${ }^{1,11}$, SERGE HERSON $^{2}$, DAVID KLATZMANN $^{1}$ and ROGER LACAVE ${ }^{12}$
}

\begin{abstract}
Departments of ${ }^{1}$ Biotherapies, ${ }^{2}$ Internal Medicine and ${ }^{3}$ Urology, AP-HP, Groupe Hospitalier Pitié Salpêtrière; ${ }^{4}$ Department of Urology, AP-HP, Necker Hospital; Departments of ${ }^{5}$ Urology and ${ }^{6}$ Oncology, AP-HP, Tenon Hospital, Paris; ${ }^{7}$ Hôpital Saint André, Metz; ${ }^{8}$ Department of Hematology, AP-HP, Necker Hospital; ${ }^{9}$ Department of Pathology,

AP-HP, Tenon Hospital; ${ }^{10}$ Department of Pathology, AP-HP, Groupe Hospitalier Pitié Salpêtrière, Paris;

${ }^{11}$ Department of Immunology, Institute for Biomedical Research, Rouen University Hospital, University of Rouen, Inserm U519 (IFRMP), Rouen; ${ }^{12}$ Department of Histology, AP-HP, Tenon Hospital, Paris, France
\end{abstract}

Received February 26, 2009; Accepted May 6, 2009

DOI: 10.3892/ijo_00000368

\begin{abstract}
Cytotoxic chemotherapy is ineffective in metastatic renal cancer. However, systemic administration of interleukin 2 (IL-2) or infusion of dendritic cells (DCs) loaded with tumor extracts can lead to some response rates with concomitant survival improvements. We report the results of a phase I-II pilot study combining DCs and IL-2 where six patients were included. DCs were derived from bone marrow $\mathrm{CD} 34^{+}$cells and loaded with autologous tumor extracts. CD34-DC vaccines were infused subcutaneously at day $45,52,59,90$ and 120 following surgery in combination with IL-2, that was subsequently administrated after the 3rd and 4th DC vaccinations. Preparation of tumor extracts and CD34-DCs were satisfactory in all patients but one. Due to rapid tumor progression, one patient was excluded before vaccination. In the 4 remaining patients, two received 3 vaccinations, while the 2 others received 5 vaccinations and the full IL- 2 treatment. No adverse effect due to the vaccinations was observed. A specific immune response against autologous tumor cells
\end{abstract}

Correspondence to: Professor François M. Lemoine, Department of Biotherapies, Bâtiment CERVI, 83 Boulevard de L'Hôpital, 75651 Paris Cedex, France

E-mail: francois.lemoine@upmc.fr

${ }^{*}$ Contributed equally

Key words: immunotherapy, dendritic cells, renal cell carcinoma, $\mathrm{CD} 34^{+}$cells, interleukin 2 , regulatory T-cells was observed in the 2 patients who completed the treatment. Interestingly, these 2 patients had a more prolonged survival than the patients receiving 3 vaccinations. Importantly, a transient and massive increase of circulating natural regulatory T-cells (nTregs) was evidenced in 3 patients following IL-2 administration. Overall, the use of CD34-DC vaccines is feasible, safe and non-toxic. A specific antitumor immune response can be detected. However, our data highlights that IL-2 is a potent inducer of nTregs in vivo and as such may have a negative impact on cancer immunotherapy.

\section{Introduction}

Cytotoxic chemotherapy is usually ineffective for metastatic renal cancer and particularly renal cell carcinoma (RCC), which have a poor prognosis with a median survival of less than a year. Systemic administration of cytokines such as interleukin 2 (IL-2) (1-4), interferon- $\alpha$ (5) or both (6,7) can lead to response rates varying from 7 to $26 \%$ with concomitant improvements of survival (8). This suggests that renal cancer could be a good candidate for immune-based therapies. Likewise, cellular immunotherapy approaches have been proposed including allogeneic stem cell transplantation (9), ex vivo expansion of lymphokine activated killer cells (LAK) and tumor infiltrating lymphocytes (TIL) $(8,9)$ and, more recently, vaccination with dendritic cells (DCs). DCs are powerful antigen-presenting cells (APCs) that play a major role in initiating primary immune responses against microbial, tumoral or self antigens. They elicit T-cell immune responses by presenting antigens on major histocompatibility complex (MHC) class I and class II molecules to both naive and memory CD8 and CD4 
T-cells (10-12). The possibility to generate in vitro functional DCs from peripheral blood monocytes (13-16) or from $\mathrm{CD}_{34}{ }^{+}$progenitors obtained from cord blood (17-19), bone marrow (BM) or cytokine mobilized peripheral blood (20-23) has opened a new field of vaccine-based immunotherapy for cancer. Thus, various DC-based clinical trials have been performed for treatment of metastatic RCCs using either tumor lysate-pulsed DCs (24-26), tumor cell-DC hybrids (27-29), tumor RNA-transfected DCs (30) or more recently DCs loaded with HLA-A2-restricted MUC1-derived peptides (31). These clinical trials performed with monocyte-derived DCs (Mo-DCs) provide evidence of relatively good biological immune anti-tumor responses, but low clinical responses. Improvements can be expected by using DCs derived from CD34 progenitors (CD34-DCs) instead of MoDCs (32-35). CD34-DCs that are less homogenous than MoDCs, contain two major myeloid DC subsets, i.e. Langerhans cells and interstitial dermal-type DC, and seem able to achieve a large immune response $(36,37)$. Interestingly, DC-based immunotherapy can be also combined to IL-2 administration $(24,38)$ or to anti-angiogenic drugs that have recently proven their efficiency in the treatment of advanced RCCs (39).

Therefore, we designed a pilot study in which 6 patients with advanced metastatic renal cancer received tumor extractpulsed CD34-DC vaccines in combination with IL-2 administered subcutaneously (s.c.) after the 3rd and the 4th vaccination (for protocol design see Fig. 1). We introduced the IL-2 treatment in combination with vaccination because it is commonly accepted that IL-2 is a good adjuvant treatment that can trigger/reinforce anti-cancer effector immune responses.

DCs were produced from $\mathrm{CD} 34^{+}$purified cells, taking into account the opportunity of the general anesthesia required for surgery to harvest bone marrow cells. Thus, we showed the feasibility of producing large amount of DCs generated from $\mathrm{BM} \mathrm{CD} 34^{+}$cells in a closed system using clinical grade reagents and GMP conditions. Vaccination was well tolerated and could induce specific anti-tumor responses. However, we surprisingly observed that IL-2, albeit routinely used in the treatment of advanced RCC, resulted in a massive increase of natural regulatory $\mathrm{T}$-cells (nTregs) with the potential to hamper vaccination efficacy.

\section{Materials and methods}

Patients characteristics, eligibility criteria and study design. Patients were included in this multi-center study upon the following criteria: $>18$ age $<70$ years; inclusion at time of diagnosis (i.e. prior to any treatment); primary tumor volume of at least $10 \mathrm{~cm}^{3}$ when estimated by tomodensitometry; RCCs with clear-cell histopathology and bi-dimensionally measurable metastatic lesions; Karnofski's performance status $>60$; expected survival of $>6$ months. Exclusion criteria were: patients with history of other cancers, autoimmune diseases or infections such as HIV, HBV, HCV; presence of brain metastasis: solid organ allograft with immunosuppressive treatment (corticosteroids and/or other immunosuppressive drugs); pregnancy; other immunotherapy or chemotherapy within 4 weeks prior to inclusion. All patients gave a written informed consent. The study was approved by an Institutional
Review Board and the 'Agence Française de Sécurité Sanitaire des Produits de Santé' (AFSSaPS) in September 2002. The clinical characteristics of the patients are presented in Table I. The design of the trial is summarized in Fig. 1. In brief, bone marrow (BM) cells were harvested under general anesthesia immediately after total nephrectomy. BM-CD $34^{+}$cells were purified and used for production of CD34-DCs while tumor extracts were prepared from the tumor. Four to six weeks after surgery, DCs generated in a closed system were pulsed with tumor extracts and injected into patients. For each patient, 6 productions of pulsed-CD34-DCs were carried out, 5 of them were utilized for vaccinations and the remaining one being used for immunomonitoring assays. The treatment schedule was as follows: eligible patients received at least 5 vaccinations of $2-4 \times 10^{5}$ tumor extract-pulsed DCs per $\mathrm{kg}$ of body weight, suspended in $5 \mathrm{ml}$ of $\mathrm{NaCl} 0.9 \%$. The vaccine was administered s.c. in a single injection site. Treatment was repeated every week for the first three vaccinations and monthly for vaccination 4 and 5. Immunomonitoring was assessed before the 1 st injection, after the 3 rd vaccination and one month after the final vaccination by collecting peripheral blood (PB) for functional analysis of T-cells. The patients also received s.c. recombinant human IL-2 (Proleukin ${ }^{\circledR}$, Chiron Corp, Amsterdam, The Netherlands) during 2 cycles of 4 weeks (i.e. 5 injections of $18 \times 10^{6} \mathrm{IU}$ at week 1,2 injections of $18 \times 10^{6}$ $\mathrm{IU}+3$ injections of $9 \times 10^{6} \mathrm{IU}$ at week 2, 3 and 4) after the 3rd and the 4th DC-injections according to standard clinical practices.

Clinical grade reagents. The culture medium used throughout this study was RPMI-1640 without phenol red (Invitrogen Corporation, Paris, France) containing 10\% secured human AB serum (hABs purchased from Etablissement Français du Sang, Rhône-Alpes, France) and $2 \mathrm{mM}$ L-glutamine. The following human recombinant cytokines approved for clinical use were: Stem Cell Factor (SCF, Amgen, Thousands Oaks, CA, USA), Flt3-Ligand (Flt3-L, Immunex, Seattle, WA, USA), Granulocyte-Macrophage Colony-Stimulating Factor (GM-CSF, Leucomax ${ }^{\circledR}$, Schering Plough, Levallois-Perret, France), Interleukin 4 (IL-4, Strathmann, Hamburg, Germany), Tumor Necrosis Factor $\alpha$ (TNF $\alpha$, Boerhinger Mannheim, Mannheim, Germany).

Preparation of autologous tumor extracts and establishment of tumor cell lines. Fresh tumor samples obtained from primary tumors were minced into $1-2 \mathrm{~mm}^{3}$ fragments and placed in RPMI-1640 under sterile conditions. Single cell suspensions were obtained by digesting the samples in $50 \mathrm{ml}$ of RPMI containing $0.75 \mathrm{mg} / \mathrm{ml}$ collagenase (Liberase ${ }^{\circledR}$, Roche diagnostics, Meylan, France) and $30 \mathrm{IU} / \mathrm{ml}$ DNase (Pulmozyme ${ }^{\circledR}$, Roche Laboratories). After, 4 to 5 cycles of digestion, cells were centrifuged at $400 \mathrm{x}$ g for $12 \mathrm{~min}$, counted and cell viability evaluated after trypan blue exclusion. An aliquot of the cell suspension was stained by May-Grünwald-Giemsa and the cell content evaluated by light microscopy examination. Some of tumor cell suspensions were immediately cryopreserved and others were cultured at $2 \times 10^{5}$ cells/ml in DMEM containing $10 \%$ fetal calf serum (FCS) for 10 days and frozen to use them in immunomonitoring assays (see below). 
A

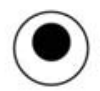

Dendritic cell production

CD34 cell thawing and initiation of dendritic cell culture

GM-SCF, SCF, TNF- $\alpha$, Flt3-L

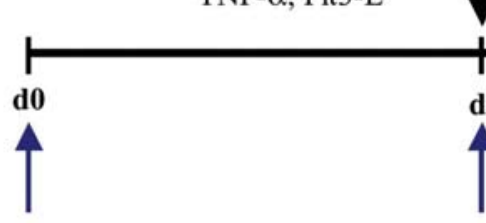

Cell count \& viability, Sterility

Cell Count, \& viability Immunophenotype Characterization Sterility
Injection into patients

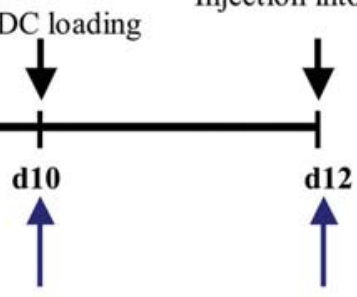

Cell Count \& $\quad$ Cell count \& viability, viability Sterility Morphology Immunophenotype Characterization Sterility

\section{Quality control}

B

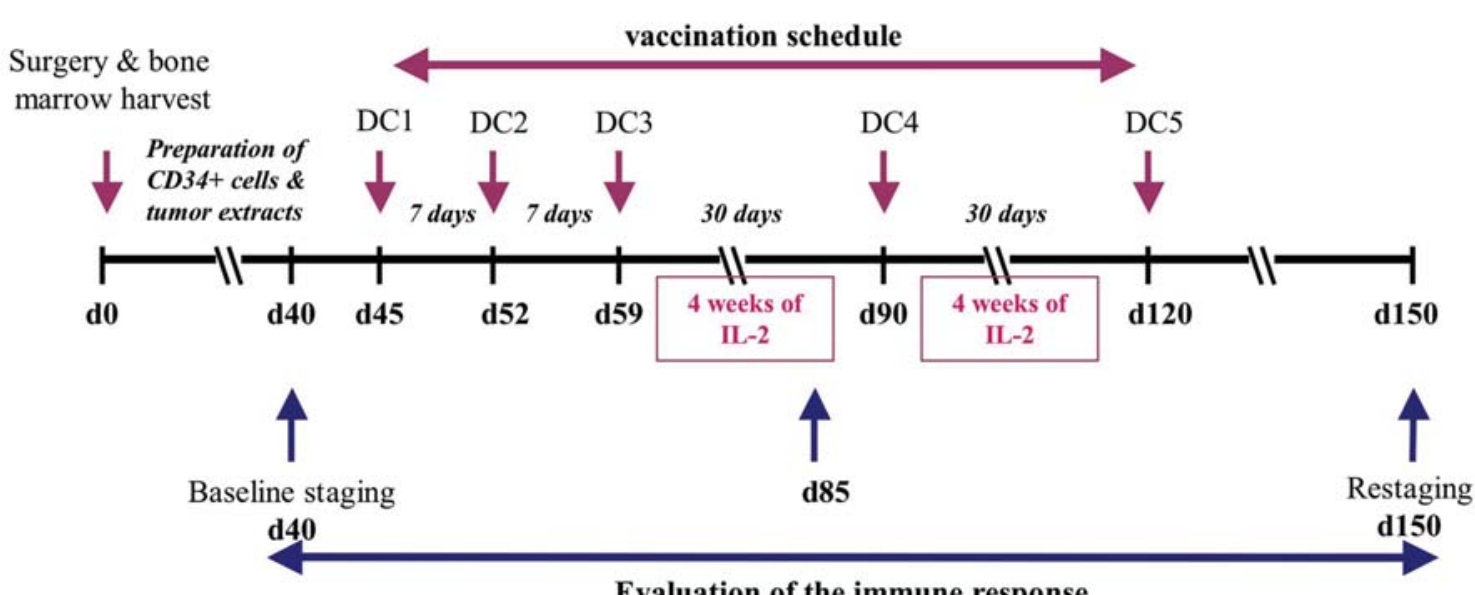

Figure 1. Scheme of the production of DCs (A), study design and vaccination schedule (B). (A) Schematic representation of the different steps for the production of tumor extract-loaded DCs derived from CD34+ cells including the different quality controls carried out in process and on the final cell product. (B) Schematic representation of the clinical trial proposed to the patients and of the different time points for the evaluation of the immune response.

Table I. Patients characteristics and disease status before surgery.

Primary tumor

\begin{tabular}{lcccccc}
\hline Patients UPN & Ages/gender & Type & Tumor staginga $^{\text {a }}$ & Nodal status $^{\mathrm{a}}$ & Furhmann grading $^{\text {Evaluable metastases }}$ \\
\hline 101 & 37/F & RCC & PT3 & N2 & IV & Chest \\
201 & 55/M & RCC & PT2 & Nx & IV & Chest, bone \\
401 & 68/F & RCC & PT3a & Nx & III-IV & Chest, liver, adrenal gland \\
402 & 56/M & RCC & PT3 & N0 & III & Chest \\
501 & 50/M & RCC & PT3a & Nx & III-IV & Bone \\
502 & 43/M & Sarcoma & ND & ND & ND & Bone \\
\hline
\end{tabular}

RCC, renal cell carcinoma; F, female; M, Male and ND, not determined. a According to Bostwick and Murphy (40).

For tumor extracts, cells were conditioned in $50 \mathrm{ml}$ cryocyte bags (Nexell international, Wemmel, Belgium), lysed by 4 to 5 freeze (liquid nitrogen) and thaw (room temperature) cycles. Lysis was monitored by light microscopy on the percentage of viable cells after trypan blue exclusion. Tumor extracts were then centrifuged at $1,000 \mathrm{x}$ g for $12 \mathrm{~min}$, supernatants were collected and protein contents determined. Microbiologic examination of extracts was also performed. Tumor extracts were aliquoted and stored at $-30^{\circ} \mathrm{C}$ until use. 
Positive selection of $\mathrm{CD} 34^{+}$cells from BM samples. Bone marrow harvests were collected in $500 \mathrm{ml}$ heparinized culture bags. All manipulations were carried out in closed system under standardized operating procedures (SOP). Cells were washed in PBS, platelets were removed and mononuclear cells (MNCs) were separated by Ficoll density centrifugation using a COBE ${ }^{\mathrm{TM}} 2991$ cell washer (COBE BCT, Lakewood, CO, USA). Then, cells were washed twice and processed for positive $\mathrm{CD} 4^{+}$selection according to the manufacturer's instructions (Miltenyi Biotec, Bergisch-Gladbach, Germany), with minor modifications during the cell labeling. After Ficoll gradient, MNCs were transferred in $600 \mathrm{ml}$ transfer pack (TP) bags (Baxter, Maurepas, France), then centrifuged at $400 \mathrm{x} \mathrm{g}$ at $20^{\circ} \mathrm{C}$ for $10 \mathrm{~min}$. The supernatant was discarded into TP bags using a plasma extractor, then the cell pellet was carefully resuspended and removed into $150 \mathrm{ml}$ TP bags for labeling. The cells were washed again in PBS/EDTA buffer (Miltenyi Biotech) supplemented with $1 \%$ of human serum albumin (HSA, LFB, Courtaboeuf, France). Up to $1 \times 10^{10} \mathrm{MNC}$ were resuspended in $90 \mathrm{ml}$ of PBS/EDTA buffer $+1 \%$ HSA (wash buffer) and incubated at room temperature in the presence of human gamma globulin (Tegeline $50 \mathrm{mg} / \mathrm{ml}, \mathrm{LFB}$ ) at a final concentration of $1.5 \mathrm{mg} / \mathrm{ml}$ for $15 \mathrm{~min}$. CliniMacs CD34+ reagent $(7.5 \mathrm{ml})$ was added to each $1 \times 10^{10} \mathrm{MNC}$ and cells were incubated at room temperature for $30 \mathrm{~min}$. The cells were then washed twice in complete buffer and resuspended in wash buffer to give a final volume of $100 \mathrm{ml}$ containing $<2 \times 10^{7} \mathrm{MNC} / \mathrm{ml}$. The cells were transferred into a single $600 \mathrm{ml}$ TP bag (Baxter) that was connected to the CliniMacs device (Miltenyi Biotec). The device was used following the manufacturer's SOP using the described washing buffer. The cells were retained after separation in $42-45 \mathrm{ml}$ of washing buffer into $150 \mathrm{ml}$ TP bags. Positively selected CD34+ cells were fractioned in $10 \mathrm{ml}$ of buffer $+4 \%$ HSA and cryopreserved in liquid nitrogen in $50 \mathrm{ml}$ cryocyte bags (Baxter) until use. Cell aliquots were taken before and after selection for various quality controls such as cell counts and viability staining with trypan blue, FACS analysis, determination of clonogenic growth and microbiologic examination.

Production in closed system of pulsed DCs derived from $\mathrm{CD} 34^{+}$cells. At day 0, for initiation of culture, a CD34+ aliquot was thawed and washed twice in complete buffer (4\% HSA). $\mathrm{CD}_{3} 4^{+}$cells were then cultured at $10^{5}$ cells $/ \mathrm{ml}$ in $85 \mathrm{~cm}^{2} \mathrm{X}$ Fold bag (Nexell international) in RPMI-1640 without phenol red supplemented with L-glutamin, $10 \%$ (vol/vol) hABs and containing $300 \mathrm{ng} / \mathrm{ml} \mathrm{SCF}, 300 \mathrm{ng} / \mathrm{ml} \mathrm{Flt3-L,} 100 \mathrm{ng} / \mathrm{ml}$ GM-CSF and $5 \mathrm{ng} / \mathrm{ml} \mathrm{TNF} \alpha$. The bags were identified and incubated in a humidified $5 \% \mathrm{CO}_{2}$ atmosphere at $37^{\circ} \mathrm{C}$. At day 5,8 , and 10 , cells were harvested, washed in cold $1 \mathrm{X}$ PBS. Then, the cell pellet was carefully resuspended in culture medium and counted. The cells were replated at $2.5-5 \times 10^{5}$ cells $/ \mathrm{ml}$ in culture medium containing the same cytokines than at day 0 except that Flt3-L was used at $50 \mathrm{ng} / \mathrm{ml}$ and that IL-4 was added at $50 \mathrm{ng} / \mathrm{ml}$. At day 10 , cells were pulsed with autologous tumor extracts $\left(100 \mu \mathrm{g} / 10^{6}\right.$ cells $)$ in complete medium at room temperature for $4 \mathrm{~h}$. Cells were then loaded with $50 \mu \mathrm{g} / \mathrm{ml}$ Keyhole Limpet Hemocyanin (KLH, Vacmune ${ }^{\circledR}$, Biosyn, France) for at least 2 h. After pulsing, DCs were cultured in bag for 48 additional hours. At day 12, pulsed DCs were washed twice and conditioned in a $5 \mathrm{ml}$ final volume of $0.9 \% \mathrm{NaCl}$. While different quality controls were performed during the production process and on the final cell product (see below), vaccine release criteria were: i) negative bacterial culture $48 \mathrm{~h}$ prior to injection, ii) cell number $2-4 \times 10^{5}$ cells $/ \mathrm{kg}$ of body weight, iii) cell viability $\geq 85 \%$, iv) CD1a expression $\geq 30 \%$ or HLA-DR $\geq 50 \%$ in cell preparation vaccine as determined by immunophenotypic analysis. When pulsed DCs were not used for vaccination, they were aliquoted and frozen for immunomonitoring. In at least one DC preparation per patient, part of the DC culture was not pulsed at day 10. This was done in order to obtain aliquots of non-pulsed DCs that will be also used for immunomonitoring, as well as for evaluating the eventual toxicity of tumor extracts on DCs.

Quality controls for evaluation of CD34 selection. Numeration of $\mathrm{CD} 34^{+}$cells and clonogenic progenitors were performed before and after selection by flow cytometry and semi-solid culture assays, respectively.

CD34 counts. The numeration and the viability of CD34+ progenitors was performed by flow cytometry using the Stem-Kit (Beckman Coulter, Villepinte, France) according to the manufacturer's instructions. This kit contains a set of reagents including CD34 and CD45 mAbs and Stem-Count Fluorospheres, and allows the direct determination of the absolute count of $\mathrm{CD}_{3} 4^{+}$cells. Exclusion of dead cells was achieved using the 7-aminoactinomycin D intercalating DNA dye.

Semi-solid culture assays for clonogenic progenitors. Cells $\left(10^{5}\right.$ and $10^{4}$ cells $\left./ \mathrm{ml}\right)$ were plated in methylcellulose cultures before and after CD34 selection, respectively. For granulomacrophage colony forming unit (CFU-GM) assay, methylcellulose medium supplemented with appropriate cytokines (Methocult H4435, StemCell Technologies, Meylan, France) was used. For dendritic cell colony forming unit assay (CFU-DC), cells were cultured in methylcellulose medium (Methocult H4230, StemCell Technologies) supplemented

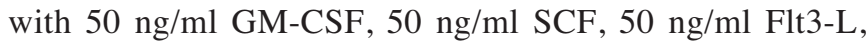
$50 \mathrm{ng} / \mathrm{ml} \mathrm{IL}-4$ and $12 \mathrm{ng} / \mathrm{ml} \mathrm{TNF} \alpha$ as described elsewhere (41). Cells were incubated at $37^{\circ} \mathrm{C}$ in a humidified incubator containing 5\% $\mathrm{CO}_{2}$ during 12 and 14 days for CFU-DC assay and CFU-GM assay, respectively. The colonies were then visualized and scored with an inverted microscope.

Quality controls of the production of pulsed-DCs. For each production of pulsed DCs, different quality controls were performed including cell morphology, immunophenotyping and mixed leukocyte reaction (MLR).

Cell morphology. At day 5 and 12, cell aliquots were washed twice with $1 \mathrm{X}$ PBS, adjusted at a concentration of $5 \times 10^{5} \mathrm{DC} / \mathrm{ml}$ and $2-5 \times 10^{5}$ cells were spun onto microscope slides. These cytospin preparations were stained with May-GrünwaldGiemsa and analyzed by light microscopy.

Immunophenotyping of DCs. After 12 days of culture, cells were double stained with the following murine anti-human 
mAbs directly conjugated either to fluorescein isothiocyanate (FITC) or to phycoerythrin (PE): CD1a-FITC (Ortho Diagnostic, Raritan, NJ, USA); CD1a-PE, CD14-FITC and CD83-PE (Beckman Coulter); CD40-FITC, CD54-PE, CD80-PE, CD86-PE and HLA-DR-PE (BD Biosciences, Mountain View, CA, USA). Negative controls were irrelevant isotype-matched mAbs. Briefly, $10^{5}$ cells were incubated with the appropriate $\mathrm{mAbs}$ at $4^{\circ} \mathrm{C}$ for $20 \mathrm{~min}$, washed twice in PBS/2\% FCS and then fixed in PBS containing $1 \%$ paraformaldehyde before analysis by flow cytometry.

Mixed leukocyte reaction (MLR). The functional ability of produced pulsed DCs to stimulate allogeneic T-cells was assessed by MLR, as described elsewhere (41).

Clinical follow-up of the patients. Follow-up was designed to evaluate both safety and efficiency of the pulsed DC/ Proleukin ${ }^{\circledR}$ treatment. First, during the five month after the 1 st DC-vaccination, an intensive follow-up was engaged, appreciating both tolerance and initial anti-tumor efficiency. Then, an additional long-term follow-up, until the end of the study, was started to evaluate possible progression disease and overall survival.

Tolerance was appreciated both immediately after each vaccination and during the intervals between the DC injections by recording any potential physical or biological toxic adverse effect according to the World Health Organization criterias and by evaluating the performance status according the Karnofski's index. Potential auto-immune disorders were evaluated by physical examination and laboratory analysis before the 1 st and 4 th vaccinations and after the 5 th vaccination. At these times, blood sample were collected for anti-nuclei, -DNA, -tissus, -microsome, -thyroglobulin, -TSH receptor and -peroxydase auto-antibodies, and also for Latex and Waaler-Rose reactions and free-T4 and TSH hormones as well as for immunomonitoring assays.

\section{Immunomonitoring}

Delayed-type hypersensitivity (DTH). Delayed-type hypersensitivity skin tests were performed with autologous DCs pulsed or not with either tumor extracts $(5 \mu \mathrm{g})$, keyhole limpet hemocyanin $(\mathrm{KLH}, 5 \mu \mathrm{g})$ or tuberculin as recall antigen. Viable DCs $\left(5 \times 10^{5}\right)$ were injected intradermally before the 1 st vaccination, after the 3 rd vaccination and one month after the final vaccination. A positive skin reaction was defined as $>5 \mathrm{~mm}$ diameter erythema and induration appearing 48-72 $\mathrm{h}$ after intradermal injection.

Characterization of T-cell subsets. For cell surface staining, various combinations of the following murine anti-human mAbs directly conjugated either to FITC, phycoerythrin (PE), PerCP or Allophycocyanine (APC) were used: CD3, CD4, CD8, CD25, CD27, CD28, CD45RA, CD45RO, CD62L, CD127, CCR7, HLA-DR. Negative controls were appropriate irrelevant isotype-matched mAbs. Briefly, cells were incubated with the appropriate $\mathrm{mAbs}$ at $4^{\circ} \mathrm{C}$ for $20 \mathrm{~min}$, washed twice in PBS containing $2 \%$ of FCS, then fixed in PBS containing $1-4 \%$ paraformaldehyde before analysis by flow cytometry using a FACScalibur (Becton-Dickinson).
Detection of nTregs in PBMC collected from patients was performed at different time points: before vaccination at day 40 , after the 3 rd vaccination and the 1 st cycle of IL-2 at day 85 , and one month after the 2nd cycle of IL- 2 and the 5th vaccination at day 150 . nTregs are known to be $\mathrm{CD}^{+}{ }^{+} \mathrm{CD} 4^{+}$ cells expressing high levels of CD25 (CD25 $\left.{ }^{\text {hi }}\right)$, the transcription factor Foxp3, and low levels of CD127 (CD127 low/-) $(42,43)$. Thus, PBMC were thawed, simultaneously stained with CD3, $\mathrm{CD} 4, \mathrm{CD} 25 \mathrm{mAbs}$ and either CD127 mAbs or with rat antihuman FOXP3-APC (PCH101 clone, eBioscience, San Diego, CA, USA). Rat IGg2a APC was used as isotype control (eBiosciences).

Detection of anti-tumoral responsive cells. Detection of tumor-responsive cells was based on the frequency of interferon- $\gamma(\mathrm{IFN}-\gamma)$ and perforin producing cells. Tumor extract-pulsed DCs and non-pulsed DCs were thawed and co-cultured with autologous PBMCs $(\mathrm{DC} / \mathrm{PBMCs}$ ratio $=1 / 10)$ collected from patients at different time points. Cells were co-cultured in RPMI containing $10 \% \mathrm{hABs}$, IL-2 (20 U/ml) and IL-7 (10 ng/ml, Cytheris, Vanves, France) in 24-well plate $\left(10^{6}\right.$ cells/well, $2 \mathrm{ml} /$ well $)$ for 2 weeks, half medium and cytokines being renewed every 3-4 days. Then, cells were co-cultured with autologous RCC tumor cells obtained as described above at two different effector/tumor cells ratio (E/T: $25 / 1$ and 10/1) for $5 \mathrm{~h}$ in RPMI containing $10 \% \mathrm{hABs}$ and $1 \mu \mathrm{g} / \mathrm{ml}$ GolgiStop (Becton-Dickinson) to block cytokine secretion. Cells alone or stimulated with PHA + ionomycin were used as negative and positive controls, respectively. The cells were then harvested, washed and stained with CD3PerCP and CD8-APC (both from Becton-Dickinson). Cells were then permeabilized with Cytofix/Cytoperm plus (Becton-Dickinson) for $30 \mathrm{~min}$ followed by two washes in Perm/Wash solution (Becton-Dickinson). Intracellular staining was then performed with anti-IFN- $\gamma$-FITC and perforin-PE or a matched isotype control antibody for $30 \mathrm{~min}$, washed twice in Perm/Wash solution, fixed in $2 \%$ paraformaldehyde and analyzed by flow cytometry using a FACSCalibur (BectonDickinson).

For cell immunophenotyping and intracellular cytokine detection at least 10,000 and 100,000 gated events were collected in a listmode file, respectively. Then, analyses were carried out using CellQuest (Becton-Dickinson) or FlowJow (Tree Star, San Carlos, CA, USA) software. Results were expressed as a percentage of positive cells and/or by median of fluorescence intensity (MFI) by comparison to negative controls.

\section{Results}

Tumor samples and bone marrow harvests from the 6 patients included in this study were obtained and processed.

Purification of $\mathrm{CD}_{34}{ }^{+}$cells from bone marrow harvests. The mean volume of BM harvests and the mean number of cells were $667.2 \pm 58.7 \mathrm{ml}$ and $11.8 \pm 1.1 \times 10^{9}$, respectively. Results of the CD34 purification are presented in Table II. After platelet removal, MNCs were enriched by Ficoll gradient allowing to obtain between 1.75 to $5.1 \times 10^{9}$ MNCs except for patient $\mathrm{P} \# 101$. Indeed, this patient had a severe inflammatory 


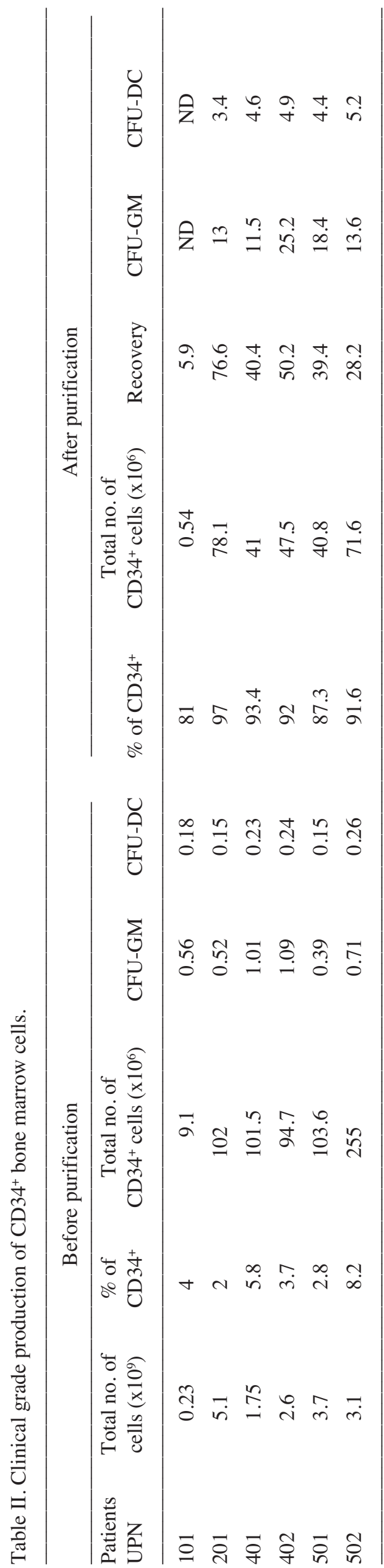

syndrome favoring BM clotting that in turn resulted in technical adverse problems and subsequently to an insufficient number of $\mathrm{CD}^{2} 4^{+}$cells $\left(0.54 \times 10^{6}\right.$ cells $)$. For the 5 remaining patients, the mean number and the mean percentage of $\mathrm{CD} 4^{+}$cells obtained after purification were $55.8 \pm 8 \times 10^{6}$ cells and $92.3 \pm 1.6 \%$, respectively. Functional study of myeloid (CFU-GM) and dendritic (CFU-DC) progenitors indicates that the purification process led to $25 \pm 6$-fold and $22.5 \pm 1.8$-fold enrichments for CFU-GM and CFU-DC, respectively. Overall, the purification of $\mathrm{BM}-\mathrm{CD} 34^{+}$cells using the CliniMacs device was satisfactory in 5 out of 6 patients. Then, CD34+ cells were aliquoted and stored in liquid nitrogen.

Preparation of autologous tumor extracts. Cell suspensions from tumor samples were obtained for all patients following nephrectomy. Then, tumor extracts were prepared. The criteria for releasing tumor extracts in order to yield sufficient numbers of pulsed DCs for 5 vaccinations were as follows: i) number of viable cells after 4-5 freeze and thaw cycles $\leq 1 \%$; ii) sterility of the product; iii) protein content $\geq 30 \mathrm{mg}$. While the size and weight of each tumor sample that we could used for extract preparation depended upon the size of the primitive tumor, the number of cells present in cell suspensions and the protein contents of the extracts did not appear to correlate to the size of tumor samples due to tumor heterogeneity in term of necrosis and vascularization (Table IIIA). Cell suspensions were characterized by morphology examination (Table IIIB). The results indicate that cell suspensions contained at least 50\% (50-90\%) of tumor cells. Thus, the preparation of tumor extracts was satisfactory in all patients as the protein content, varying from 31.4 to $161.7 \mathrm{mg}$, was sufficient enough for pulsing at least $3 \times 10^{8}$ DCs at day 10 of culture.

Clinical grade production of CD34-DCs pulsed with tumor extracts. As mentioned above, the number of $\mathrm{CD} 34^{+}$cells obtained in patient P\#101 was not sufficient enough and for this reason production of DCs was not further carried out. Patient P\#502 was excluded from the study due to the sarcomatous histopathological type of his primary tumor despite a satisfactory production of both $\mathrm{CD} 34^{+}$cells and tumor extracts. Thus, clinical grade production of DCs was performed in 4 out of 5 eligible patients. The recovery of $\mathrm{CD}^{2} 4^{+}$cells after thawing was $\geq 70 \%$ giving $11.4 \pm 1.5 \times 10^{6}, 4 \pm 0.7 \times 10^{6}$, $5.1 \pm 0.8 \times 10^{6}$ and $6 \pm 0.4 \times 10^{6} \mathrm{CD} 34^{+}$cells for patients P\#201, P\#401, P\#501 and P\#402, respectively. The mean growth curves for each patient showing the proliferation and differentiation of CD34+ into DCs are presented in Fig. 2A. Cells first proliferate giving rise to a mean number of $41-58 \times 10^{6}$ and $17.8-20.7 \times 10^{6}$ cells at day 8 and 10 , respectively. After day $8-10$, cell proliferation decreases while the differentiation process increases. The results concerning the amount of DCs and the number of vaccinations that we could produce for each patient at day 12 are summarized in Table IIIC. Thus, 16 clinical grade productions used for vaccinations were prepared giving rise to $20.6 \pm 2.4 \times 10^{6}$ pulsed-DCs from $7.4 \pm 0.9 \times 10^{6} \mathrm{CD} 34^{+}$cells. In addition, productions of unpulsed and pulsed-DCs were also performed for each patient in view of the immunomonitoring particularly for DTH tests. Overall, these data indicate the feasibility of the cryopreservation and 
Table III. Clinical grade production of tumor extracts and CD34-DCs.

A, Generation of tumor extracts from tumor samples

\begin{tabular}{lcccr}
\hline $\begin{array}{l}\text { Patients } \\
\text { UPN }\end{array}$ & $\begin{array}{c}\text { Weight of tumor } \\
\text { samples }(\mathrm{g})\end{array}$ & $\begin{array}{c}\text { Tumor cell suspension } \\
\left(\mathrm{x} 10^{9}\right)\end{array}$ & $\begin{array}{c}\text { No. of tumor cells } \\
\text { used for extracts }\left(\mathrm{x} 10^{6}\right)\end{array}$ & $\begin{array}{c}\text { Protein content } \\
(\mathrm{mg})\end{array}$ \\
\hline 101 & 5.2 & 0.26 & 216 & 33.9 \\
201 & 25.1 & 1.09 & 997 & 161.7 \\
401 & 57.4 & 1.27 & 900 & 93.7 \\
402 & 17.3 & 0.37 & 340 & 31.4 \\
501 & 3 & 0.16 & 148.4 & 69.2 \\
502 & 17.2 & 1.63 & 1414 & 104.3 \\
\hline
\end{tabular}

B, Cytological analysis of tumor cell suspensions

\begin{tabular}{|c|c|c|c|c|c|}
\hline \multicolumn{6}{|c|}{ Percent $(\%)$ of total cells } \\
\hline Patients UPN & Lymphocytes & Macrophages & Siderophages & Polymorphonuclear cells & Tumor cells \\
\hline 201 & $30 \%$ & $<10 \%$ & $<10 \%$ & $<5 \%$ & $60-70 \%$ \\
\hline 401 & $<10 \%$ & $<10 \%$ & $<5 \%$ & $<1 \%$ & $60 \%$ \\
\hline 402 & $<10 \%$ & $<5 \%$ & $<5 \%$ & $<10 \%$ & $80-90 \%$ \\
\hline 501 & $20 \%$ & $10-15 \%$ & $5-10 \%$ & $3 \%$ & $50 \%$ \\
\hline 502 & $<10 \%$ & $<1 \%$ & $<1 \%$ & $<1 \%$ & $90 \%$ \\
\hline
\end{tabular}

\section{C, CD34-DCs}

\begin{tabular}{|c|c|c|c|c|c|}
\hline \multicolumn{6}{|c|}{ Production of CD34-DCs for vaccinations $\left(\times 10^{6}\right)$} \\
\hline Patients UPN & Production 1 & Production 2 & Production 3 & Production 4 & Production 5 \\
\hline 201 & $24.6(11.2)$ & $19.8(9.5)$ & $10.9(10)$ & $2.8(9.1)$ & $37.3(17.7)$ \\
\hline 401 & $11.28(3.5)$ & $30.5(5.8)$ & $29.8(3.9)$ & ND & ND \\
\hline 402 & $18.3(6.5)$ & $17.4(6.8)$ & $21.3(5.9)$ & $12.5(5.4)$ & $39.1(7.7)$ \\
\hline 501 & 15.4 (6.7) & $20.9(4.7)$ & $17.7(3.9)$ & ND & ND \\
\hline
\end{tabular}

In brackets, are the number of $\mathrm{CD} 34^{+}$cells seeded in culture for generating DCs. ND, Not done.

differentiation of $\mathrm{BM}-\mathrm{CD} 34^{+}$into $\mathrm{DCs}$ in a reproducible manner.

Immunophenotyping and characterization of dendritic cells in the final clinical grade cell products. At day 12 of culture, viable cells were counted and cell aliquots were stained with various mAbs and analyzed by flow cytometry in order to assess the DC content of each production. Table IVA displays for each patient the mean percentage \pm SEM of different markers that are known to be expressed by DCs at day 12 of culture. Importantly, $>75 \%$ of the cells expressed HLA-DR. $25-45 \%$ of the cells also expressed the CD80 and CD86 costimulatory molecules and 30-70\% were CD40-positive. Since CD1a was expressed at day 5 of culture by $>30 \%$ of the cells (not shown), this marker which strongly varied from one patient to another, decreased after day 8 of culture and particularly after loading of DCs with tumor extracts. The relatively low levels of expression of co-stimulatory molecules and CD1a are due to the fact that cultures were carried out in the presence of hABs instead of FCS and IL-4, respectively. As observed by others (35), CD34-derived DCs weakly expressed CD83. Finally, $<10 \%$ of the cells expressed CD14 as the cultures were carried out in the presence of IL-4 (19). Analysis of Giemsa-stained cytospins showed the presence within final cell products of cells with typical DC morphology (not shown). The functionality of DC to stimulate T-cells was assessed in an MLR assay (Fig. 2B)

Vaccination of the patients, safety and tolerance. As we were able to fulfill the releasing criteria for each DC production, cell products were injected as described in Fig. 1. As shown in Table IIIC, P\#201 and P\#402 received 5 vaccinations, the mean of viable cells injected per $\mathrm{kg}$ of body weight were $2 \pm 0.5 \times 10^{5}$ and $2.3 \pm 0.4 \times 10^{5}$, respectively (Table IVB). Patients $\mathrm{P} \# 401$ and $\mathrm{P \# 501}$ only received 3 vaccinations because of progressive tumor growth and/or requirement of other 
$\mathrm{P} \# 201$

A

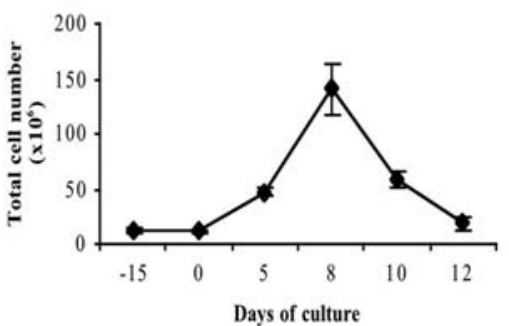

$\mathrm{P} \# 402$

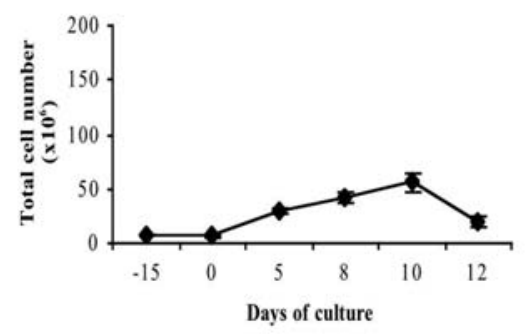

B
P $\# 201$
$\mathrm{P} \# 401$

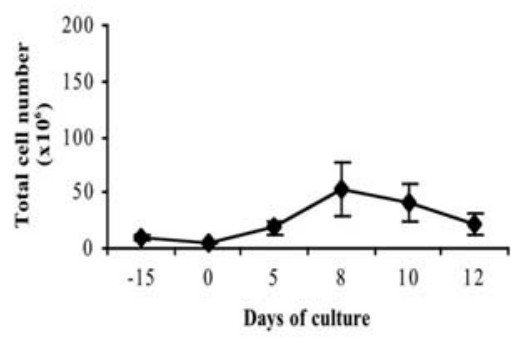

P\#501

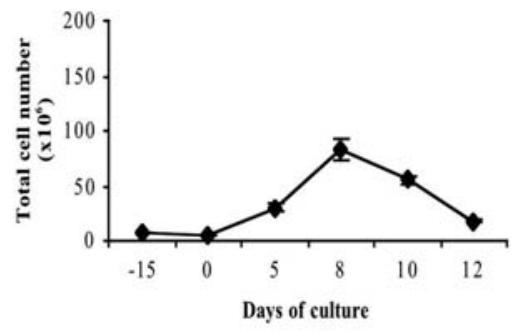

4401

P\#501
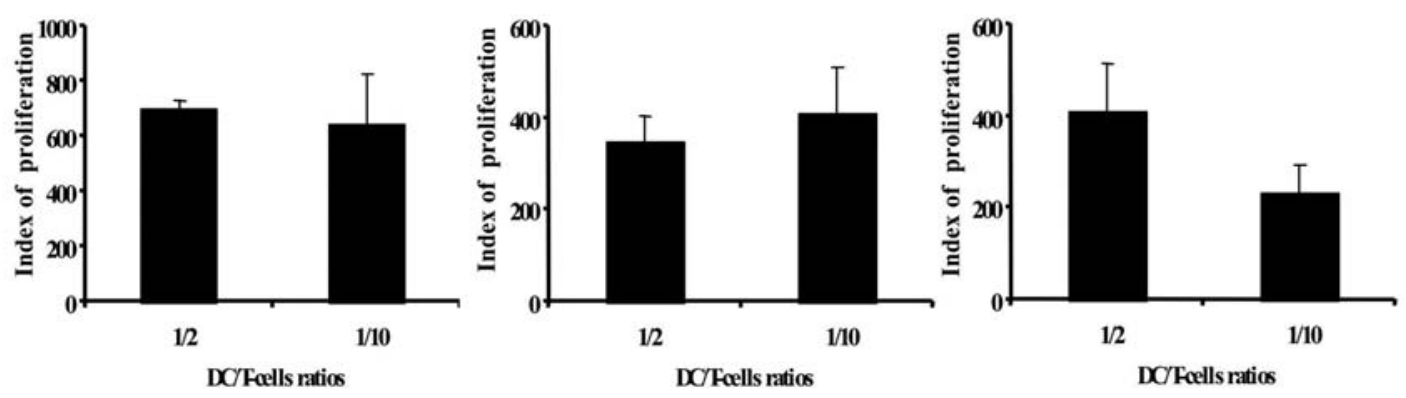

Figure 2. Growth curves (A) and functional study (B) of DCs differentiated from BM-CD34+ cells. (A) Each curve is the mean \pm SEM of $n$ (see Table IIIC) DC productions expressed in total cell number for patient \#201, \#401, \#501 and \#402, respectively. (B) Stimulation of allogeneic T-cells by CD34-DCs. DCs and allogeneic T-cells were co-cultured in triplicate at different DC/T-cell ratio $(1 / 2,1 / 10)$ for 5 days, and T-cell proliferation was measured by tritiated thymidine incorporation as described elsewhere (41). Results for each patient are presented as the mean of 2-3 different MLR, each corresponding to separate DC production. The results have been normalized by presenting T-cell proliferation as an index of proliferation calculated as follows: [DC/T-cells mixed cultures (cpm) - T-cells cultured alone (cpm)]/[ T-cells cultured alone (cpm)]. The mean number of cpm at a 1/2 ratio for patient 201, 401 and 501 were $78450 \pm 2850,78850 \pm 12300$ and $86650 \pm 17200$, respectively.

treatments that will excluded these patients from the present study. Indeed, P\#401 developed a cardiac failure associated with an acute renal failure and P\#501 had a medullar compression due to cervical metastasis which required high doses of corticoids in view of surgery. These two patients were injected with $2.7 \pm 1.2 \times 10^{5}$ and $2.5 \pm 0.2 \times 10^{5}$ per $\mathrm{kg}$ of body weight, respectively (Table IVB). Thus, the total number of viable cells injected into the patients ranged from 47.7 to $73.1 \times 10^{6}$ cells. In the four patients receiving pulsed-DCs, initial and delayed tolerance was excellent without clinical nor biological adverse effect due to the vaccinations. No patient developed erythema at the injection site nor systemic toxicity following vaccination. No biological nor clinical manifestations of auto-immune disease developed in these patients.

Follow-up of the patients and study of the immunological responses

Delayed-type hypersensitivity. In order to evaluate DTH which reflects the in vivo $\mathrm{T}$-cell response, patients were injected intradermally with either tuberculin as a recall antigen, KLH, tumor extracts alone, unloaded DCs or DCs loaded with tumor extracts before vaccination (d40), after the 3rd vaccination and the first round of IL-2 (d85) and one month after the 5th vaccination and IL-2 treatment (d150). In none of the patients receiving 3 or 5 vaccinations, a positive DTH could be observed. The absence of positive DTH for tuberculin in all patients except one (patient \#201) strongly suggests that patients were immuno-depressed.

Evidence of tumor reactive $C D 8^{+} T$-cells. Blood samples from the 2 patients who had completed the full vaccination protocol were tested for the presence of tumor extract reactive $\mathrm{CD}^{+}$ T-cells (Fig. 3). The results showed an increase of the percentage of IFN- $\gamma$ and perforin-positive $\mathrm{CD}^{+} \mathrm{T}$-cells after restimulation with tumor-extract pulsed DCs by comparison to negative controls (i.e. PBMC stimulated with non-pulsed DCs) as soon as after 3 vaccinations and 4 weeks of IL-2. These increases were still detectable, albeit less important, one month after the full treatment was achieved. These data 
Table IV. Characterization of dendritic cell vaccines.

A, Immunophenotype

\begin{tabular}{lccccrrrr}
\hline Patients UPN & HLA-DR & CD1a & CD80 & CD86 & CD40 & CD83 & CD14 & n \\
\hline 201 & $76.2 \pm 1.7$ & $16.2 \pm 0.4$ & $29.9 \pm 16.7$ & $27.9 \pm 0.3$ & $33.6 \pm 0.5$ & $9.7 \pm 0.6$ & $2.3 \pm 1.1$ & 5 \\
401 & $99.2 \pm 0.1$ & $30.4 \pm 2.0$ & $32.5 \pm 0.8$ & $44.8 \pm 1.1$ & $68.9 \pm 1.1$ & $17.8 \pm 0.5$ & $9.5 \pm 2.5$ & 3 \\
402 & $87.8 \pm 1.7$ & $4.4 \pm 0.4$ & $26 \pm 2.3$ & $36.8 \pm 2.2$ & $51.6 \pm 2.4$ & $11.2 \pm 1.8$ & $5 . \pm 1.1$ & 5 \\
501 & $86.9 \pm 1.6$ & $10.9 \pm 3.5$ & $25.4 \pm 6.7$ & $40 . \pm 6.8$ & $57.1 \pm 4.1$ & $15.6 \pm 0.3$ & $4.6 \pm 0.2$ & 3 \\
\hline
\end{tabular}

Expression of each cell surface marker is presented as mean percentage \pm SEM. $n$, number of productions.

B, Number of injected cells

\begin{tabular}{|c|c|c|c|c|c|}
\hline Patients UPN & $\begin{array}{c}\text { Total cell no. of } \\
\text { injected cells }\left(\times 10^{6}\right)\end{array}$ & $\begin{array}{l}\text { Mean of injected } \\
\text { cells }\left(\times 10^{6}\right)\end{array}$ & $\begin{array}{l}\text { Total cell no./Kg } \\
\qquad\left(\mathrm{x} 10^{5}\right)\end{array}$ & $\begin{array}{c}\text { Mean of cells } / \mathrm{Kg} \\
\left(\mathrm{x} 10^{5}\right)\end{array}$ & $\begin{array}{c}\text { No. of } \\
\text { vaccinations }\end{array}$ \\
\hline 201 & 68.3 & $13.6 \pm 3.3$ & 10 & $2 \pm 0.5$ & 5 \\
\hline 401 & 55.3 & $18.4 \pm 8.5$ & 8.2 & $2.7 \pm 1.2$ & 3 \\
\hline 402 & 73.1 & $14.6 \pm 2.6$ & 11.7 & $2.3 \pm 0.4$ & 5 \\
\hline 501 & 47.7 & $15.9 \pm 1.4$ & 7.7 & $2.5 \pm 0.2$ & 3 \\
\hline
\end{tabular}

Numbers are mean percentage \pm SEM of $\mathrm{n}$ vaccinations.

indicate that vaccination of metastatic RCC patients with tumor-pulsed DCs derived from $\mathrm{CD} 34^{+}$cells can elicit a specific anti-tumor biological immune response.

Effect of vaccination and IL-2 on T-cell subsets. No significant imbalance among naive and memory T-cell subsets was observed before, during and after vaccination (data not shown). Before vaccination, the study of nTregs in 3 patients indicated that the frequency of $\mathrm{CD}^{+}{ }^{+} \mathrm{CD} 4{ }^{+} \mathrm{FOXP} 3^{+} \mathrm{T}$-cells $(2.2,2.6$ and $4.6 \%)$ remained in the normal range as compared to a control group of healthy donors $(3 \pm 0.7 \%, \mathrm{n}=9)$. At day 85 (one month after 3 vaccinations and just after the first 4 weeks of IL-2), a striking increase of nTregs was observed (Fig. 4). Interestingly, the percentage of $\mathrm{CD}^{3}+\mathrm{CD} 4+\mathrm{FOXP} 3+$ cells returned to baseline levels one month (day 150) after the complete treatment (i.e. 5 vaccinations and two cycles of 4 week IL-2). The characterization of nTregs based on CD25 ${ }^{\text {hi }}$ or CD127 low/- expression gave rise to similar data (not shown). These data strongly suggest that IL-2 treatment may transiently increase the percentage of circulating nTregs in RCC patients.

Clinical outcome. One patient (P\# 501) progressed rapidly during the round of vaccinations (cervical and dorsal bone metastasis) and was excluded from the study after the 3rd vaccination to start a second line of treatment by interferon- $\alpha$ and conventional chemotherapy. He died of progressive disease 10 months after diagnosis. In the three patients who received Proleukin ${ }^{\circledR}$, moderate to elevated transient fever was observed. This was clearly linked to the course of this cytokine treatment. In one patient (P\#201), this led to reduction of the Proleukin dosage for the last four weeks of the treatment. In another patient (P\#401), the Proleukin induced saline inflation leading to severe cardiac dysfunction and subsequent acute renal failure regressing upon arrest of Proleukin. This patient died from pulmonary embolism.

No tumor regression was evidenced in treated patients. However, in the two patients who received five DC vaccinations, one (P\#201) displayed a stable disease during the rounds of DC vaccinations, and then evidenced pulmonary progression shortly after. He died 16 month after initial diagnosis. The other (P\#402) also had stable disease for 6 months from the 1st DC vaccination, then he had pulmonary progression of the disease 6 weeks after the 5 th DC vaccination. At this time, he received an anti-angiogenic treatment followed by conventional chemotherapy. However, the disease continued to progress and the patient died 24 months after initial diagnosis.

\section{Discussion}

In this study we have shown the feasibility of producing large amount of clinical-grade CD34+-derived DCs pulsed with tumor extract under GMP conditions and the absence of toxicity after vaccination of metastatic RCC patients with these cell products. Most of the DC-based clinical trials have been carried out using Mo-DCs, and only few of them have used CD34-DCs $(23,35)$, CD $34^{+}$cells being obtained from G-CSFmobilized peripheral blood hematopoietic stem cells. In this study, we have used BM CD34-DCs, BM cells being harvested during the general anesthesia. This approach can be proposed to cancer patients requiring surgery and will also have the advantage of avoiding the use of G-CSF. Indeed, besides its transient and uncomfortable side effects (i.e. pain and fever), G-CSF can favor tumor growth, as some tumor cells express 
P\#201
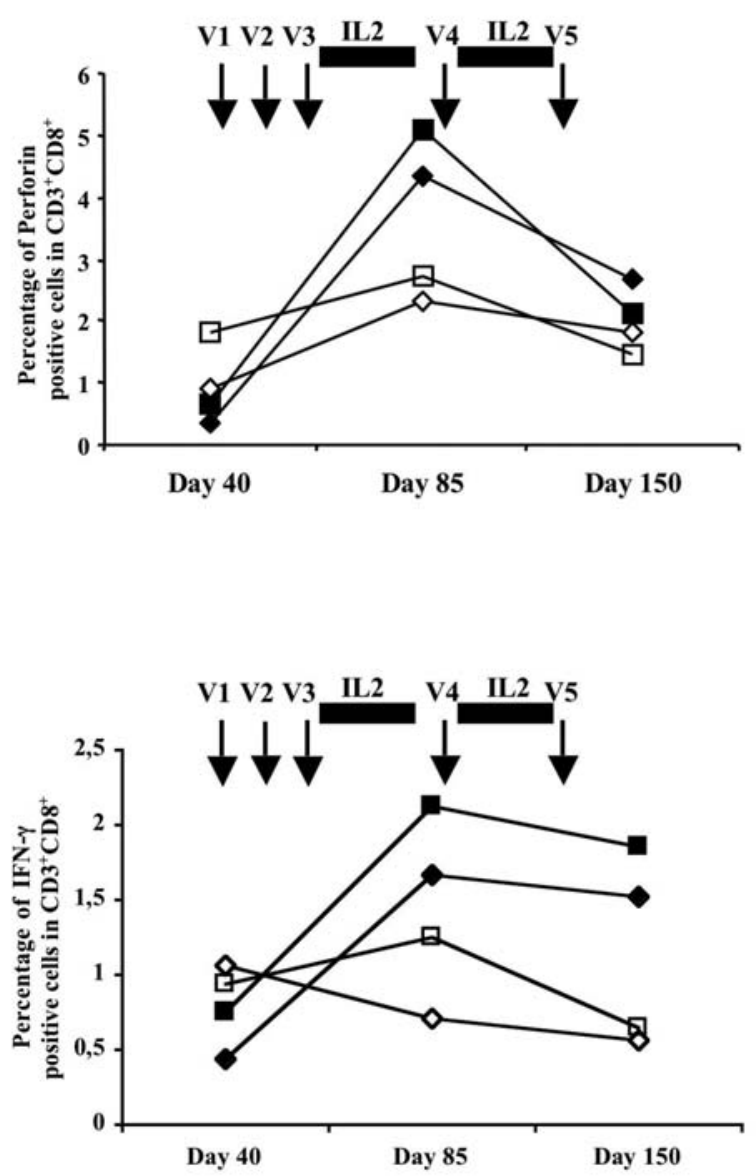

P\#402
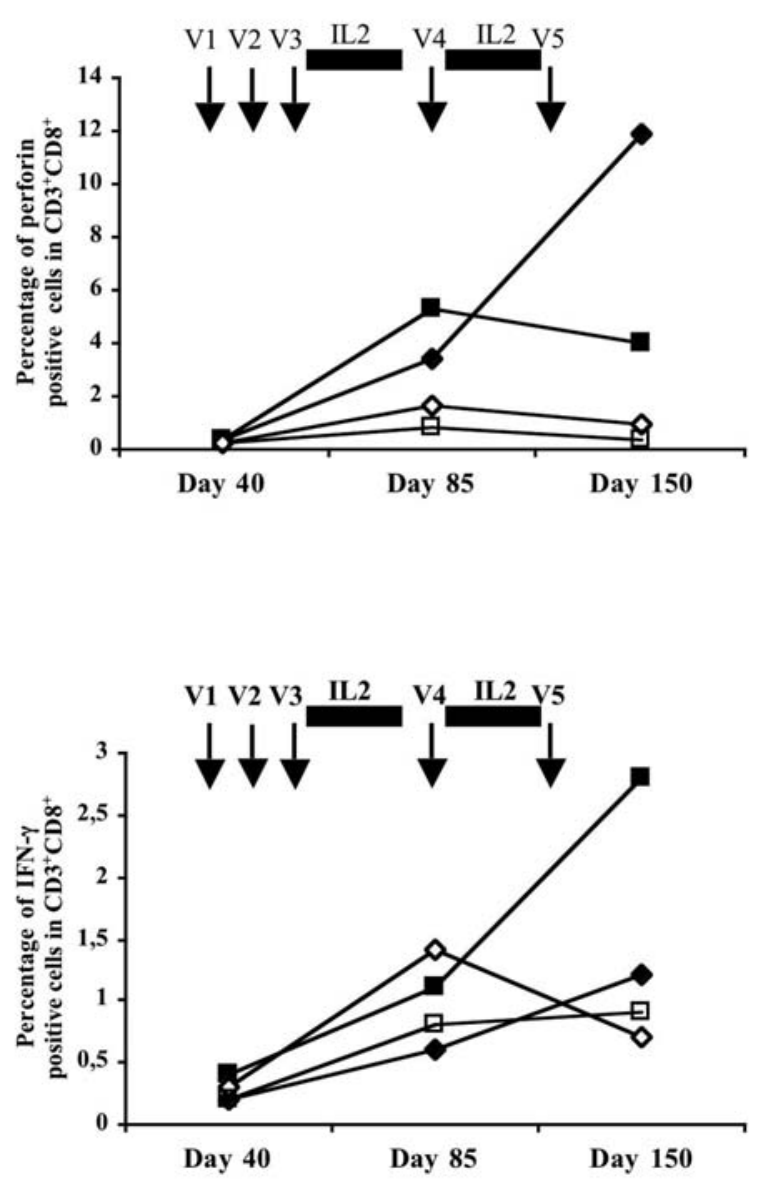

Figure 3. Kinetics of the biological immune response. Evaluation of the anti-tumoral responses was based on the frequency of $\mathrm{CD} 3^{+} \mathrm{CD} 8^{+}$cells producing IFN- $\gamma$ or perforin. PBMC, collected at different time points (day 40, day 85 and day 150), were co-cultured either with autologous tumor extract-pulsed DCs (filled symbols) or unpulsed DCs (open symbols) in the presence of low doses of IL-2 and IL-7 for 2 weeks. Then, primed cells were restimulated by autologous tumor cells derived from RCC at two E/T ratio: 25/1 (diamond symbols) and 10/1 (square symbols) for $5 \mathrm{~h}$. Then, production of IFN- $\gamma$ and perforin was determined by flow cytometry after gating analysis on $\mathrm{CD} 3^{+} \mathrm{CD} 8^{+}$cells. Data presented are from the two patients that received the full vaccination treatment and arrows represent the schedule of the vaccinations. $\bullet$ T-cells primed with tumor extract-pulsed DCs and co-cultured with target cells at $25 / 1$ ratio. $\diamond, T$-cells primed with unpulsed DCs and co-cultured with target cells at 25/1 ratio. $\mathbf{\square}$, T-cells primed with tumor extract-pulsed DCs and co-cultured with target cells at 10/1 ratio. $\square$, T-cells primed with unpulsed DCs and co-cultured with target cells at 10/1 ratio.

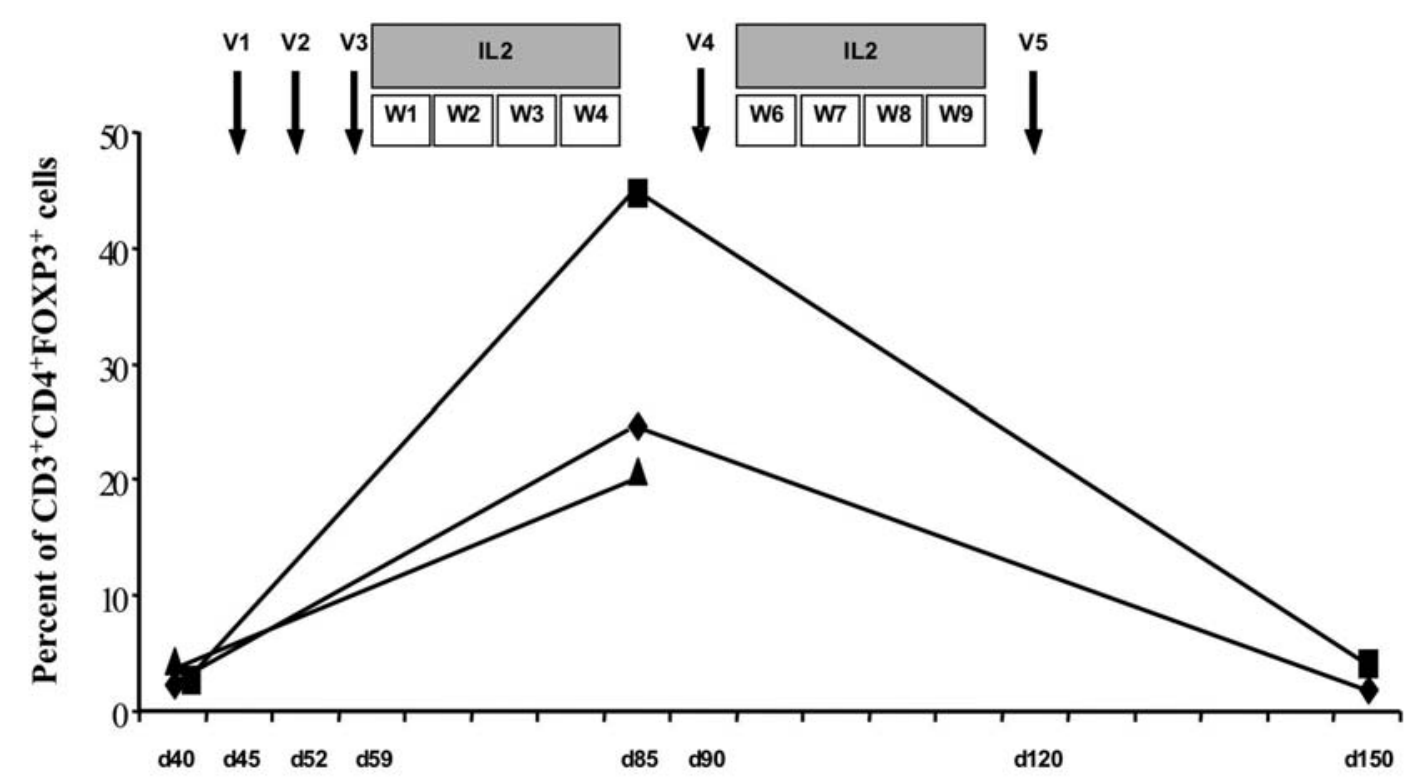

Figure 4. Follow-up of nTreg during the protocol study. nTreg were identified by flow cytometry based on FOXP3 expression gated within CD3 ${ }^{+}$CD4+ T-cells. Arrows represent the schedule of the vaccinations. Symbols for each patient studied are: $\bullet$ for patient \# 201; $\mathbf{\Delta}$ for patient \# 401; $\mathbf{\square}$ for patient \# 402. 
such growth factor receptors (44) and also disturb the balance between different $\mathrm{T}$-cell subsets $(45,46)$. In our study, we observed a decrease of the cell growth after 8 days of culture (see Fig. 2A), yet allowing injecting an average amount of $2-2.7 \times 10^{5}$ cells $/ \mathrm{kg}$ (see Table IIIB). According to the data reported by Banchereau et al (35), it seems possible to load CD34-DCs at day 8 and to inject them into the patients at day 9 to achieve an efficient immune response. Thus, it should be worthwhile to test this setting in a future clinical trial in order to increase the number of injected cells and to decrease the culture duration. In addition, the sequenced exposure of CD34+ cells to various cytokines (i.e. Flt3-L plus IL-6 and then GM-CSF) seems important to favor their differentiation into tumor-competent DCs (47). Although our CD34-DCs were produced in the presence of Flt3-L and GM-CSF, IL-6 was not used. Nevertheless, an anti-tumor immunological response was evidenced in the two patients having received the full vaccination treatment. This was demonstrated, in the absence of specific and well-identified tumor associated antigen, by generating for each patient a continuous tumor cell line. Thus, we were able to obtain, by using CD34-DCs loaded with total tumor cell extracts, an immune response specifically directed against autologous tumor cells. This indicates that our final DC product can induce T-cell stimulation rather than tolerance.

However, while we did not observe an increased immune responses after the 4th and the 5th vaccination, we believe that this was due to the fact that patients received their IL-2 treatment after the 3rd vaccination. Indeed, we observed that the percentage of circulating nTregs massively increased after the first cycle of IL-2 administration that followed the 3rd DC vaccination. They represented $>30 \%$ of the whole CD4 T-cell population.

Our data are in agreement with previous studies $(48,49)$ indicating that high-dose bolus IL-2 administration increased peripheral blood nTregs as well as nTregs in the tumor microenvironment (50) in patients with metastatic melanoma or RCC. Although we observed that the percentage of nTregs rapidly returned to baseline levels one month after the cessation of IL-2, it is thus striking that a cytokine initially given for boosting effector immune responses may actually drive primarily the nTreg expansion. Our observation may have major implication since there are numerous pieces of evidence that nTregs play a key role in tumor development in mice and humans (51). In the 2 patients receiving both 5 DC vaccines and IL-2, no tumor progression was observed during the treatment. Nevertheless, our data suggest that IL-2 admini-stration may counterbalance the beneficial effect of the DC vaccines for inducing an anti-tumor T-cell response. Our results should be taken into consideration in future DCbased clinical trials and IL-2 administration avoided particularly in advanced RCC patients where the percentage of circulating nTregs seems to be basically increased (52).

Overall, we report the possibility of using BM-CD $34^{+}$cells for producing large number of clinical grade DCs that can be injected into cancer patients without any toxic effect. Because only few patients could undergo the complete protocol due to the severity of their pathology, DC-based immunotherapy should be envisioned in a more favorable context. Indeed, prognosis of metastatic RCC patients has been recently and considerably improved by anti-angiogenic drug therapy (53). However, eliciting an efficient anti-tumor immune response to eliminate residual tumor cells and/or to control tumor growth still remains a challenge. Thus, one can propose to combine anti-angiogenic drug therapies with DC-based immunotherapy and in vivo Treg depletion (54) in order to reinforce the immune stimulation $(51,55)$. Indeed, in vivo Treg depletion both in different animal tumor models (56) and in cancer patients (57) has been proven to enhance the anti-tumor immune response. Other strategies consisting of either inhibiting indoleamine 2,3-dioxygenase (IDO) (58) or blocking B7-H1 (59), two pathways involved in immune suppression in cancer, would also be of interest.

Furthermore, directing the immune response to recently identified tumor-associated antigens such as MUC1 (38), carbonic anhydrase IX-G250MN (CA9) (60) or survivin (61) in RCC cancer patients should also be progressed in order to improve the efficacy of such cell therapy strategies. Our data also prompt to consider re-evaluating the use of IL-2 in gene and cell therapies of cancer.

\section{Acknowledgements}

We thank Dr Olivier Rixe (AP-HP, Groupe Hospitalier Pitié Salpêtrière, Department of Oncology, Paris, France) for helpful discussions. We thank Virginie Leclercq, Céline Pellé, Anne Gaignerie, Pierre Cheraud, Marie-Christine Burland, Véronique Bon-Durand for their expert technical assistance. This study was granted by the 'Projet Hospitalier de Recherche Clinique (PHRC)' and M.C. was financially supported by PHRC.

\section{References}

1. Gore ME, Galligioni E, Keen CW, et al: The treatment of metastatic renal cell carcinoma by continuous intravenous infusion of recombinant interleukin-2. Eur J Cancer 30A: 329-333, 1994.

2. Rosenberg SA, Yang JC, Topalian SL, et al: Treatment of 283 consecutive patients with metastatic melanoma or renal cell cancer using high-dose bolus interleukin 2. JAMA 271: 907-913, 1994.

3. Fyfe G, Fisher RI, Rosenberg SA, Sznol M, Parkinson DR and Louie AC: Results of treatment of 255 patients with metastatic renal cell carcinoma who received high-dose recombinant interleukin-2 therapy. J Clin Oncol 13: 688-696, 1995.

4. Yang JC, Sherry RM, Steinberg SM, et al: Randomized study of high-dose and low-dose interleukin-2 in patients with metastatic renal cancer. J Clin Oncol 21: 3127-3132, 2003.

5. Pyrhonen S, Salminen E, Ruutu M, et al: Prospective randomized trial of interferon alfa-2a plus vinblastine versus vinblastine alone in patients with advanced renal cell cancer. J Clin Oncol 17: 2859-2867, 1999.

6. Negrier S, Escudier B, Lasset C, et al: Recombinant human interleukin-2, recombinant human interferon alfa-2a, or both in metastatic renal-cell carcinoma. Groupe Francais d'Immunotherapie. N Engl J Med 338: 1272-1278, 1998.

7. Negrier S, Perol D, Ravaud A, et al: Randomized study of intravenous versus subcutaneous interleukin-2, and IFNalpha in patients with good prognosis metastatic renal cancer. Clin Cancer Res 14: 5907-5912, 2008.

8. van Spronsen DJ, de Weijer KJ, Mulders PF and De Mulder PH: Novel treatment strategies in clear-cell metastatic renal cell carcinoma. Anticancer Drugs 16: 709-717, 2005.

9. Tykodi SS, Warren EH, Thompson JA, et al: Allogeneic hematopoietic cell transplantation for metastatic renal cell carcinoma after nonmyeloablative conditioning: toxicity, clinical response, and immunological response to minor histocompatibility antigens. Clin Cancer Res 10: 7799-7811, 2004. 
10. Banchereau J and Steinman RM: Dendritic cells and the control of immunity. Nature 392: 245-252, 1998.

11. Steinman RM, Inaba K, Turley S, Pierre P and Mellman I: Antigen capture, processing, and presentation by dendritic cells: recent cell biological studies. Hum Immunol 60: 562-567, 1999

12. Banchereau J, Paczesny S, Blanco P, et al: Dendritic cells: controllers of the immune system and a new promise for immunotherapy. Ann NY Acad Sci 987: 180-187, 2003.

13. Zhou LJ and Tedder TF: CD $14^{+}$blood monocytes can differentiate into functionally mature $\mathrm{CD} 83^{+}$dendritic cells. Proc Natl Acad Sci USA 93: 2588-2592, 1996.

14. Palucka KA, Taquet N, Sanchez-Chapuis F and Gluckman JC: Dendritic cells as the terminal stage of monocyte differentiation. J Immunol 160: 4587-4595, 1998.

15. Cao H, Verge V, Baron C, et al: In vitro generation of dendritic cells from human blood monocytes in experimental conditions compatible for in vivo cell therapy [see comments]. J Hematother Stem Cell Res 9: 183-194, 2000.

16. Dauer M, Obermaier B, Herten J, et al: Mature dendritic cells derived from human monocytes within 48 hours: a novel strategy for dendritic cell differentiation from blood precursors. J Immunol 170: 4069-4076, 2003

17. Caux C, Massacrier C, Dezutter-Dambuyant C, et al: Human dendritic Langerhans cells generated in vitro from CD34 progenitors can prime naive $\mathrm{CD}^{+} \mathrm{T}$ cells and process soluble antigen. J Immunol 155: 5427-5435, 1995.

18. Rosenzwajg M, Camus S, Canque B, Guigon M and Gluckman JC: The influence of different cytokine schedules on human dendritic cell (DC) differentiation from cord blood CD34 ${ }^{+}$cells. Blood 88 (Suppl 1): 154a, 1996.

19. Caux C, Massacrier C, Vanbervliet B, et al: $\mathrm{CD} 34^{+}$hematopoietic progenitors from human cord blood differentiate along two independent dendritic cell pathways in response to granulocytemacrophage colony-stimulating factor plus tumor necrosis factor alpha: II. Functional analysis. Blood 90: 1458-1470, 1997.

20. Siena S, Di Nicola M, Bregni M, et al: Massive ex vivo generation of functional dendritic cells from mobilized CD34 ${ }^{+}$ blood progenitors for anticancer therapy. Exp Hematol 23: 1463-1471, 1995.

21. Bernhard H, Disis ML, Heimfeld S, Hand S, Gralow JR and Cheever MA: Generation of immunostimulatory dendritic cells from human $\mathrm{CD}_{3} 4^{+}$hematopoietic progenitor cells of the bone marrow and peripheral blood. Cancer Res 55: 1099-1104, 1995.

22. Strunk D, Rappersberger K, Egger C, et al: Generation of human dendritic cells/Langerhans cells from circulating CD34 ${ }^{+}$ hematopoietic progenitor cells. Blood 87: 1292-1302, 1996.

23. Mackensen A, Herbst B, Chen JL, et al: Phase I study in melanoma patients of a vaccine with peptide-pulsed dendritic cells generated in vitro from CD34(+) hematopoietic progenitor cells. Int J Cancer 86: 385-392, 2000.

24. Oosterwijk-Wakka JC, Tiemessen DM, Bleumer I, et al: Vaccination of patients with metastatic renal cell carcinoma with autologous dendritic cells pulsed with autologous tumor antigens in combination with interleukin-2: a phase 1 study. J Immunother 25: 500-508, 2002.

25. Holtl L, Zelle-Rieser C, Gander H, et al: Immunotherapy of metastatic renal cell carcinoma with tumor lysate-pulsed autologous dendritic cells. Clin Cancer Res 8: 3369-3376, 2002.

26. Pandha HS, John RJ, Hutchinson J, et al: Dendritic cell immunotherapy for urological cancers using cryopreserved allogeneic tumour lysate-pulsed cells: a phase I/II study. BJU Int 94: 412-418, 2004.

27. Marten A, Renoth S, Heinicke T, et al: Allogeneic dendritic cells fused with tumor cells: preclinical results and outcome of a clinical phase I/II trial in patients with metastatic renal cell carcinoma. Hum Gene Ther 14: 483-494, 2003.

28. Avigan D, Vasir B, Gong J, et al: Fusion cell vaccination of patients with metastatic breast and renal cancer induces immunological and clinical responses. Clin Cancer Res 10: 4699-4708, 2004.

29. Barbuto JA, Ensina LF, Neves AR, et al: Dendritic cell-tumor cell hybrid vaccination for metastatic cancer. Cancer Immunol Immunother 53: 1111-1118, 2004.

30. Su Z, Dannull J, Heiser A, et al: Immunological and clinical responses in metastatic renal cancer patients vaccinated with tumor RNA-transfected dendritic cells. Cancer Res 63: 2127-2133, 2003
31. Wierecky J, Mueller M and Brossart P: Dendritic cell-based cancer immunotherapy targeting MUC-1. Cancer Immunol Immunother 55: 63-67, 2006.

32. Mortarini R, Anichini A, Di Nicola M, et al: Autologous dendritic cells derived from $\mathrm{CD} 34^{+}$progenitors and from monocytes are not functionally equivalent antigen-presenting cells in the induction of melan-A/Mart-1(27-35)-specific CTLs from peripheral blood lymphocytes of melanoma patients with low frequency of CTL precursors. Cancer Res 57: 5534-5541, 1997.

33. Meierhoff G, Krause SW and Andreesen R: Comparative analysis of dendritic cells derived from blood monocytes or CD34 ${ }^{+}$ hematopoietic progenitor cells. Immunobiology 198: 501-513, 1998.

34. Ferlazzo G, Wesa A, Wei WZ and Galy A: Dendritic cells generated either from $\mathrm{CD} 34^{+}$progenitor cells or from monocytes differ in their ability to activate antigen-specific $\mathrm{CD}^{+} \mathrm{T}$ cells. J Immunol 163: 3597-3604, 1999.

35. Banchereau J, Palucka AK, Dhodapkar M, et al: Immune and clinical responses in patients with metastatic melanoma to CD34(+) progenitor-derived dendritic cell vaccine. Cancer Res 61: 6451-6458, 2001 .

36. Banchereau J, Ueno H, Dhodapkar M, et al: Immune and clinical outcomes in patients with stage IV melanoma vaccinated with peptide-pulsed dendritic cells derived from CD34+ progenitors and activated with type I interferon. J Immunother 28: 505-516, 2005

37. Cao T, Ueno H, Glaser C, Fay JW, Palucka AK and Banchereau J: Both Langerhans cells and interstitial DC cross-present melanoma antigens and efficiently activate antigen-specific CTL. Eur J Immunol 37: 2657-2667, 2007.

38. Wierecky J, Muller MR, Wirths S, et al: Immunologic and clinical responses after vaccinations with peptide-pulsed dendritic cells in metastatic renal cancer patients. Cancer Res 66: 5910-5918, 2006.

39. Sciarra A, Gentile V, Salciccia S, Alfarone A and Di Silverio F: New anti-angiogenic targeted therapy in advanced renal cell carcinoma (RCC): current status and future prospects. Rev Recent Clin Trials 3: 97-103, 2008.

40. Bostwick DG and Murphy GP: Diagnosis and prognosis of renal cell carcinoma: highlights from an international consensus workshop. Semin Urol Oncol 16: 46-52, 1998.

41. Movassagh M, Baillou C, Cosset FL, Klatzmann D, Guigon M and Lemoine FM: High level of retrovirus-mediated gene transfer into dendritic cells derived from cord blood and mobilized peripheral blood CD34+ cells. Hum Gene Ther 10: 175-187, 1999.

42. Liu W, Putnam AL, Xu-Yu Z, et al: CD127 expression inversely correlates with FoxP3 and suppressive function of human CD4 ${ }^{+}$ T reg cells. J Exp Med 203: 1701-1711, 2006.

43. Seddiki N, Santner-Nanan B, Martinson J, et al: Expression of interleukin (IL)-2 and IL-7 receptors discriminates between human regulatory and activated T cells. J Exp Med 203: 1693-1700, 2006.

44. Tachibana M, Miyakawa A, Nakashima J, et al: Autocrine growth promotion by multiple hematopoietic growth factors in the established renal cell carcinoma line KU-19-20. Cell Tissue Res 301: 353-367, 2000.

45. Franzke A, Piao W, Lauber J, et al: G-CSF as immune regulator in $\mathrm{T}$ cells expressing the G-CSF receptor: implications for transplantation and autoimmune diseases. Blood 102: 734-739, 2003.

46. Rutella S, Zavala F, Danese S, Kared H and Leone G: Granulocyte colony-stimulating factor: a novel mediator of T cell tolerance. J Immunol 175: 7085-7091, 2005.

47. Cohen PA, Koski GK, Czerniecki BJ, et al: STAT3- and STAT5-dependent pathways competitively regulate the pandifferentiation of CD34pos cells into tumor-competent dendritic cells. Blood 112: 1832-1843, 2008.

48. Ahmadzadeh $M$ and Rosenberg SA: IL-2 administration increases $\mathrm{CD}^{+}{ }^{+} \mathrm{CD} 25$ (hi) Foxp $3^{+}$regulatory $\mathrm{T}$ cells in cancer patients. Blood 107: 2409-2414, 2006.

49. van der Vliet HJ, Koon HB, Yue SC, et al: Effects of the administration of high-dose interleukin-2 on immunoregulatory cell subsets in patients with advanced melanoma and renal cell cancer. Clin Cancer Res 13: 2100-2108, 2007.

50. Jensen HK, Donskov F, Nordsmark M, Marcussen N and von der Maase H: Increased intratumoral FOXP3-positive regulatory immune cells during interleukin-2 treatment in metastatic renal cell carcinoma. Clin Cancer Res 15: 1052-1058, 2009. 
51. Curiel TJ: Regulatory T cells and treatment of cancer. Curr Opin Immunol 20: 241-246, 2008.

52. Cesana GC, DeRaffele G, Cohen S, et al: Characterization of $\mathrm{CD} 4{ }^{+} \mathrm{CD} 25^{+}$regulatory $\mathrm{T}$ cells in patients treated with high-dose interleukin-2 for metastatic melanoma or renal cell carcinoma. J Clin Oncol 24: 1169-1177, 2006.

53. Choueiri TK, Bukowski RM and Rini BI: The current role of angiogenesis inhibitors in the treatment of renal cell carcinoma. Semin Oncol 33: 596-606, 2006

54. Powell DJ Jr, Attia P, Ghetie V, Schindler J, Vitetta ES and Rosenberg SA: Partial reduction of human FOXP3 ${ }^{+} \mathrm{CD} 4 \mathrm{~T}$ cells in vivo after CD25-directed recombinant immunotoxin administration. J Immunother 31: 189-198, 2008.

55. Holtl L, Ramoner R, Zelle-Rieser C, et al: Allogeneic dendritic cell vaccination against metastatic renal cell carcinoma with or without cyclophosphamide. Cancer Immunol Immunother 54: 663-670, 2005

56. Ghiringhelli F, Larmonier N, Schmitt E, et al: $\mathrm{CD} 4{ }^{+} \mathrm{CD} 25^{+}$ regulatory $\mathrm{T}$ cells suppress tumor immunity but are sensitive to cyclophosphamide which allows immunotherapy of established tumors to be curative. Eur J Immunol 34: 336-344, 2004.
57. Dannull J, Su Z, Rizzieri D, et al: Enhancement of vaccinemediated antitumor immunity in cancer patients after depletion of regulatory T cells. J Clin Invest 115: 3623-3633, 2005.

58. Katz JB, Muller AJ and Prendergast GC: Indoleamine 2,3dioxygenase in T-cell tolerance and tumoral immune escape. Immunol Rev 222: 206-221, 2008.

59. Curiel TJ, Wei S, Dong H, et al: Blockade of B7-H1 improves myeloid dendritic cell-mediated antitumor immunity. Nat Med 9: 562-567, 2003

60. Uemura H, Fujimoto K, Tanaka M, et al: A phase I trial of vaccination of CA9-derived peptides for HLA-A24-positive patients with cytokine-refractory metastatic renal cell carcinoma. Clin Cancer Res 12: 1768-1775, 2006.

61. Mahotka C, Krieg T, Krieg A, et al: Distinct in vivo expression patterns of survivin splice variants in renal cell carcinomas. Int J Cancer 100: 30-36, 2002. 